J. N. Am. Benthol. Soc., 2008, 27(2):463-470

(C) 2008 by The North American Benthological Society

DOI: 10.1899/07-061.1

Published online: 22 April 2008

\title{
A review of freshwater gastropod conservation: challenges and opportunities
}

\author{
Steven J. Lysne ${ }^{1,6}$, Kathryn E. Perez ${ }^{2,7}$, Kenneth M. Brown ${ }^{3,8}$, \\ Russell L. Minton ${ }^{4,9}$, AND Jeffrey D. Sides ${ }^{5,10}$ \\ ${ }^{1}$ Department of Biology, Boise State University, 1910 University Way, Boise, Idaho 83725 USA \\ ${ }^{2}$ University of North Carolina at Chapel Hill and Department of Biology, Duke University, \\ Durham, North Carolina 27708 USA \\ ${ }^{3}$ Department of Biological Sciences, Louisiana State University, Baton Rouge, Louisiana 70803 USA \\ ${ }^{4}$ Department of Biology, University of Louisiana at Monroe, Monroe, Louisiana 71209 USA \\ ${ }^{5}$ Department of Microbiology, University of Alabama at Birmingham, Birmingham, Alabama 35294 USA
}

\begin{abstract}
North American freshwater gastropods remain an understudied, yet critically imperiled, fauna. As part of a larger discussion on freshwater mollusks in this special issue, we review 4 specific areas of concern regarding freshwater gastropods and discuss how best to address those concerns in the context of conservation. Areas of concern include freshwater gastropod conservation strategies, taxonomy and systematics, ecological research, and conservation challenges. We illustrate how each of these topics relates to conservation efforts and discuss opportunities to improve our baseline knowledge of freshwater gastropod taxonomy, ecology, and conservation. We emphasize throughout that effective conservation strategies require the participation of as many affected and interested groups, from local communities to governmental agencies, as possible for successful implementation and management. We offer suggestions for the direction of cooperative conservation with regard to freshwater gastropods.
\end{abstract}

Key words: freshwater gastropods, cooperative conservation, review, research, strategy, snails.

The freshwater gastropod fauna of the USA and Canada consists of 842 nominal taxa (NatureServe 2007). This fauna is increasingly imperiled by river regulation, habitat loss, poor water quality, reduced water quantity, and invasive species. Estimates suggest that $>40 \%$ of freshwater snail species are negatively affected by anthropogenic factors (Neves et al. 1997), resulting in many extinctions in North America (Master et al. 2000). More than $60 \%$ of the total nominal freshwater snail fauna have global ranks of G1 (critically imperiled), G2 (imperiled), or GH-GX (presumed or possibly extinct; Fig. 1), and recent extinctions support these rankings (Sada and Vinyard 2002, Hershler et al. 2007). Less than $1 / 4$ of all North American taxa are thought to be secure (G5) or apparently secure (G4; NatureServe 2007). The US

\footnotetext{
${ }^{6}$ E-mail addresses: steve_lysne@fws.gov

${ }^{7}$ keperez@duke.edu

${ }^{8}$ kmbrown@1su.edu

9 minton@ulm.edu

${ }^{10}$ pebblesnail@hotmail.edu
}

Fish and Wildlife Service lists 23 species of snails as endangered or threatened (Table 1).

Our objectives are to summarize what is known about freshwater gastropod conservation needs in North America (Brown et al. 2008, Perez and Minton 2008), highlight critical knowledge gaps that negatively affect conservation efforts, and suggest a logical path for future work.

\section{Background}

In the USA, freshwater gastropods are an especially diverse group of invertebrates, and their highest diversity is in the Southeast (Lydeard and Mayden 1995, Brown et al. 1998) and the Intermountain West (Frest and Johannes 2000, Hershler and Sada 2002, Hershler et al. 2007). Gastropods have invaded, and secondarily invaded, nearly every freshwater habitat in North America (Brown 2001), from emergent wetlands to shallow ponds, lakes, reservoirs, springs, creeks, streams, and large rivers. These generally small, inconspicuous members of our freshwater faunas have 

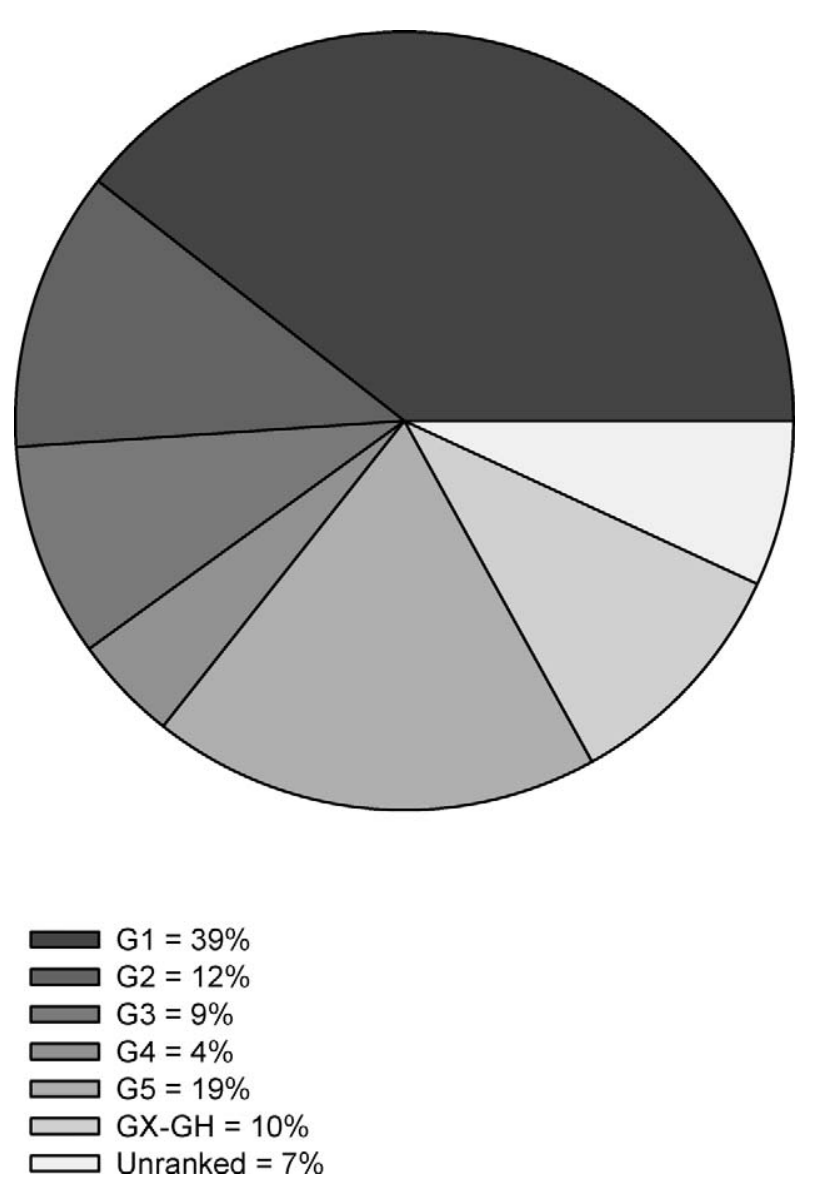

FIG. 1. Conservation rankings of North American freshwater gastropods (data from NatureServe 2007).

a disproportionately large role in the transfer of energy through aquatic systems (Newbold et al. 1983, Richardson et al. 1988, Brown 2001), primarily because of their numerical abundance in some systems. Unfortunately, their dispersal abilities, life histories, and habitat requirements do not appear to be well suited for coping with the rapid landscape changes and losses of habitat observed over the past 2 centuries in North America.

The primary causes of imperilment for listed snail species are loss or alteration of habitat. In the southeastern US, the loss of shoal habitat caused by impoundments is the cause of the extinction of many species and the tremendous reduction in range of many others (Neves et al. 1997). In the Intermountain West, the loss of spring habitats because of water withdrawal from regional aquifers and diversions of surface springs for irrigation also is of serious concern (Sada and Vinyard 2002, Myler et al. 2007). Other threats, such as water pollution and invasive species, combine with habitat loss or alteration to result in one of the best documented declines of a group of organisms worldwide (Lydeard et al. 2004).

\section{National Strategy}

Efforts to conserve native biodiversity on a large scale benefit from the formulation of a national plan, or strategy, to consolidate the energies of academics, natural resource agencies, and the public. Examples include the National Oceanic and Atmospheric Administration's Salmon Recovery Planning Strategy (NOAA 2007), the US Fish and Wildlife Service's Draft National Bald Eagle Management Guidelines (USFWS 2006), and the National Native Mussel Conservation Committee's National Strategy for the Conservation of Freshwater Mussels (NNMCC 1998). Management plans increase government and public awareness of the need for conservation, identify conservation actions necessary to achieve recovery of imperiled fauna, and foster creative partnerships to bring various actions to fruition (NNMCC 1998). Alternatives to national strategies for conservation of biodiversity include single-species conservation or recovery plans or land-management plans. However, conservation plans for species or habitats do not always have the same objectives as national strategies (e.g., to raise awareness, identify actions, and create partnerships) and might not be as useful as national strategies in leveraging funding for diverse taxa.

It is imperative that scientists and resource managers communicate with and convey information to the various publics that have an interest in the conservation of freshwater gastropods (Lydeard et al. 2004), and a comprehensive national strategy can be a vehicle for such communication. Mechanisms are in place to achieve this conservation need. The Freshwater Mollusk Conservation Society is revising its national strategy to include advances in research and understanding of freshwater mollusks and to include freshwater snails. A comprehensive national strategy might be the preeminent document that we use to leverage resources for freshwater gastropod conservation in the face of competing interests and priorities.

\section{Basic Research}

\section{Taxonomy and systematics}

The first step in a successful gastropod conservation program is to gain an understanding of the diversity of taxa that exist (Perez and Minton 2008). To protect biodiversity, we must first be able to recognize it in nature. The historical approach to taxonomy and classification of freshwater snails has been based on morphology. Unfortunately, much of this morphological evidence is difficult to use for comparison because of a lack of uniform and comparable data among authors, subjectivity of authors, and disagreement 
TABLE 1. US freshwater snail species listed as endangered (E) or threatened (T) under the Endangered Species Act of 1973.

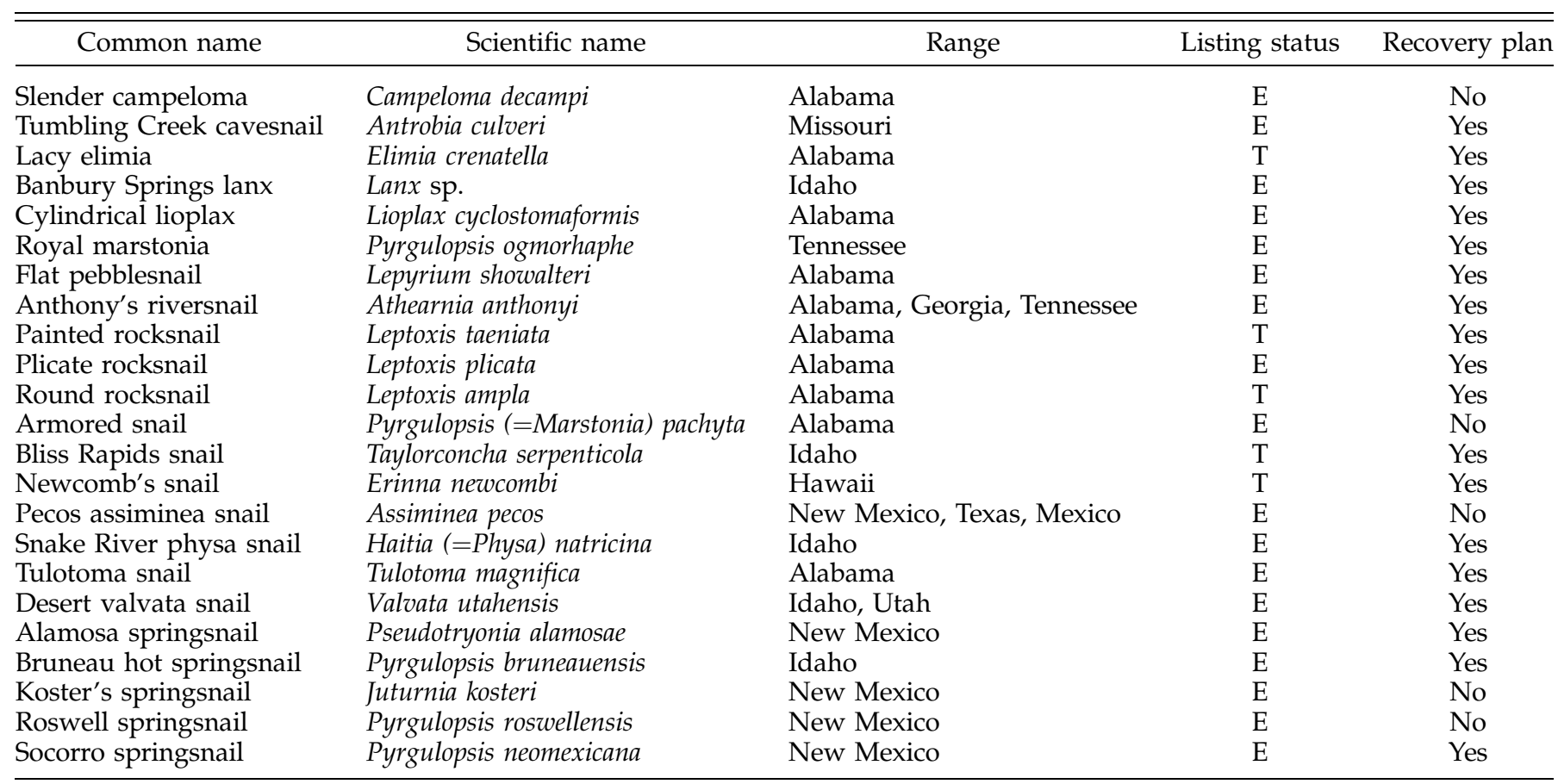

over character utility. Inconsistent taxonomy hinders conservation efforts by making information regarding specific distinctiveness equivocal. As new data are gathered and new species are described, we must update our database of taxonomic knowledge to enable conservation efforts. Those charged with implementing conservation plans generally are not taxonomists. Therefore, they should be supplied with current names and classifications; they should not be forced to determine whether names are synonymous or which methods are currently most appropriate.

We recommend the following regarding the roles of systematics and taxonomy in freshwater snail conservation efforts. First, we recommend a lineage-based concept of defining management units. New species discovered and described in this fashion are inherently testable in a scientific context (Goldstein et al. 2000, Sites and Marshall 2004) without ignoring the intellectual and scientific content of taxonomy (Dunn 2003, Lipscomb et al. 2003, Seberg et al. 2003). These units can then serve as the basis for captive propagation and other in situ and ex situ conservation efforts that preserve ecological and evolutionary processes, as well as individual populations. We recommend using a variety of data sources in defining these units, including morphology, gene sequences, and other natural history characteristics, analyzed in an evolutionary context so that natural forces and processes are retained.
We encourage authors to follow the rules of taxonomy and nomenclature when publishing descriptions or redescriptions of species. Turgeon et al. (1998) provided a list of names that is generally accepted in the field, and we recommend using it as the single starting point for modern nomenclature, with the understanding that future work probably will change it.

Conservation efforts should include recognition of unique lineages as primary management units, and the evolutionary processes that govern them should be stated explicitly. We also encourage researchers and agencies to explore the systematics and taxonomy of those groups that have not been treated in the modern literature. Large lineages, such as the families Hydrobiidae (e.g., Hershler 1994, Hershler and Ponder 1998) and Pleuroceridae (e.g., Tryon 1873, Holznagel and Lydeard 2000, Graf 2001), have had historical and recent systematic and taxonomic assessments. Smaller families, such as Physidae (Te 1978, Taylor 2003), have received disproportionate attention primarily because of their worldwide distribution (Dillon 2000). However, many evolutionary lines, such as the Valvatidae and Viviparidae, have not had any comprehensive treatments.

Ecology

Once taxonomists have stabilized specific units of conservation, then the conservation community can 
begin to address the status of those entities. The need for adequate inventories of extant taxa and an understanding of distributional trends of those taxa is urgent (Lydeard et al. 2004, Wilson 2005). We have benefited greatly in this regard from the work of ambitious scientists (Frest and Johannes 2000, Stewart and Dillon 2004, Stewart 2006) who have inventoried snail species in specific states or regions. In particular, the Freshwater Gastropods of North America Project (Dillon 2007) is an ambitious effort that will benefit from the continued contributions of scientists, and we encourage participation in this endeavor. These efforts constitute a dramatic improvement in our understanding of freshwater snail diversity, but a snapshot of extant taxa across North America is not sufficient for purposes of conservation planning. Our reliance on historical records with sometimes questionable geospatial references can lead to premature conservation decisions and inefficient use of scarce natural resource agency dollars. It is important that inventory programs be repeatable (and then actually repeated) in subsequent years to document species persistence, increases and decreases in spatial distribution, and changes in habitat condition. Some of these needs might be within our reach and will be elucidated by careful study in natural history museums and other biological research collections (Lydeard et al. 2004). In other cases, new and exciting research will have to be developed to meet the needs we have outlined.

Research is advancing in freshwater snail ecology, but authors continue to stress the paucity of information that exists for many species (Brown and Johnson 2004, Richards and Cazier-Shinn 2004, Lysne and Koetsier 2006, Miller et al. 2006). We understand the general role of snails in freshwater systems (Brown et al. 1998, Dillon 2000, Brown 2001), but many of the 842 nominal taxa have been the focus of little ecological work since their description. The available treatments are, at best, "scattered" or "restricted to statements about the snails' habitats" (Burch 1989). Contrast this understanding with the relatively vast literature on bivalve ecology (McMahon and Bogan 2001) and the need for vigorous study becomes clear.

To address these research needs, we recommend adhering to a logical progression of information gathering (i.e., stabilized taxonomy, completed inventory, reliable trend information, and all in an ecological context) so that natural resource managers can move on to the important task of setting conservation priorities. However, we acknowledge the difficulties of implementing such a strategy on a large scale and suggest that these goals can be tailored to suit individual agency needs (i.e., the crisis du jour) or research programs and still follow a practical infor- mation-gathering path. For example, a molecular study of an evolutionary lineage (i.e., taxonomy) might document and report element occurrences of particular species (i.e., inventory) and simultaneously provide a description of community composition (i.e., ecological context).

\section{Conservation Challenges}

\section{Water quantity}

Of particular importance in the conservation of freshwater snails in North America is the state of our increasingly scarce water resources. Freshwater sources around the world have been extensively developed for the production of electricity, use in irrigated agriculture, and as the water supply for our burgeoning cities and industries (Postel 2000, Hutson et al. 2005). Global water demand has tripled since the 1950s, and aquifers and river systems are increasingly overexploited (Postel 2000). As rights for surface water become more difficult to secure, users increasingly make claims for groundwater to support irrigated agriculture, aquaculture, and domestic needs-a phenomenon referred to as groundwater mining. Unfortunately, these 2 sources of freshwater are hydrologically linked, and increased use of ground water can lead to decreased flows in rivers and streams. If even conservative global population-growth and water-use projections are realized, the stresses on freshwater systems and the species that live in them are expected to increase significantly (Postel 2000).

\section{Water quality}

The need for relatively pollution-free environments is as important to gastropod conservation as is the need for available freshwater. Numerous pollutants have been documented in some aquatic systems (Clark and Maret 1998, Wong et al. 2000, Clark et al. 2004, Rattray et al. 2005), yet significant uncertainty remains regarding the effects of these pollutants on populations of freshwater snails. Conservation biologists cannot possibly keep pace with industry with regard to a reasonable understanding of the effects of existing and novel contaminants in aquatic environments. However, it is important that we attempt to understand the effect of contaminants on snails in an ecological context, and we encourage researchers to follow this line of inquiry.

\section{Invasive species}

Invasive species are another important conservation challenge that can negatively affect native freshwater snails directly through competition for resources, such 
as food and space, and indirectly through changes in ecosystem function (Hall et al. 2003, Richards 2004, Kerans et al. 2005). Species invasions have a demonstrated detrimental effect on the biodiversity of mollusks (Lydeard et al. 2004) and are the $2^{\text {nd }}$ leading cause of declines in threatened and endangered species (but see Simberloff 2003, Gurevich and Padilla 2004). The relatively recent explosion of New Zealand mudsnails (Potamopyrgus antipodarum) in the western USA is a poignant example of the conservation challenges we face (Brown et al. 2008).

\section{Putting species back}

An important challenge to conservation biologists is finding cost-effective, efficient captive-propagation and reintroduction techniques. These techniques might include reproduction and rearing of juvenile snails in captivity with subsequent release into the known historic range of a species, or less significant intervention such as relocation or translocation of eggs, juveniles, or adults from viable populations. The goals of both of these techniques are to restore species to areas of their historic ranges where they no longer exist or to augment extant populations. Unfortunately, captive propagation of snails is still very much an experimental undertaking. These conservation measures must be planned carefully because they have associated risks, such as reduction of genetic variability that could lead to inbreeding depression, introduction of disease from individuals released into the wild, and the potential that human error or equipment failure could lead to loss of captively held species (Snyder et al. 1996, USFWS 2000).

Few researchers have attempted captive propagation of freshwater snails in North America, and little published research on the topic is available. A recognizable field of reintroduction biology has emerged (Seddon et al. 2007), but in general, conservation-oriented captive-propagation work has focused largely on mammals and birds, whereas invertebrate species are grossly underrepresented (Sarrazin and Barbault 1996, Seddon et al. 2005). Significant challenges to a captive-propagation program exist. These challenges include securing adequate broodstock for imperiled species (IUCN 1998), locating suitable release sites for individuals (Lyles and May 1987, Griffith et al. 1989, IUCN 1998), determining optimal environmental requirements for growth and reproduction, and genetic concerns associated with the propagation of species from a small number of individuals. Without proper consideration of the genetic implications of artificial intervention in imperiled snail reproduction, our efforts ultimately might be more harmful than beneficial to the species we hope to save. Last, regular publication in peer-reviewed journals is crucial for effective communication of the results of propagation and reintroduction projects, whether success or failure, so that we can learn from our mistakes (Fischer and Lindenmayer 2000).

\section{Opportunities for Success}

To address these conservation challenges, we recommend establishment of local working groups that have the interest, expertise, and ability to collect, review, and disseminate information to those individuals or agencies that drive natural resource policy. These local working groups could create an agreedupon mission statement, keep detailed minutes for future reference, invite guest speakers to share information with the participants of the group, and eventually participate in natural resource conservation and management decisions. Goals of such working groups might include: 1) dissemination of applied freshwater snail research to managers, 2) advocacy for existing agency programs that protect habitats, and 3) development of new and application of existing incentives and opportunities to involve private landowners in aquatic habitat conservation and restoration. An example of an opportunity for conservation might be the recommendation of minimum instream flows, and the timing of those flows, in threatened reaches of rivers for the conservation of freshwater snails. Stream ecologists and natural resource managers recognize that natural flow regimes have important implications for benthic organisms (Poff et al. 1997, Armitage 2006), and it is reasonable to expect that such efforts would be well received by decision makers and the general public.

Local working groups also could promote the construction and maintenance of wetlands. The economic (Prato and Hey 2006) and ecosystem (Johnson and Younger 2006) benefits of wetlands are documented (Nebel and Wright 1996, National Research Council 2001, 2004). By constructing and restoring wetlands along the lengths of natural river systems, at the termini of irrigation canals, the outflows of commercial fish-production facilities, or the outflows of municipal wastewater treatment facilities, we could greatly improve the quality of water that enters our lakes and streams and, in the process, improve habitat conditions for aquatic wildlife species, including freshwater snails.

The opportunities for success with regard to invasive species are numerous. The scope of exotic species invasion, the potential impact on native biodiversity, and the uncertainty with regard to the 
magnitude of impacts present an array of research needs to the conservation community. If conservation alternatives have been exhausted and the decision to initiate a propagation program has been made, then natural resource agencies will have to commit to proper planning and sustained efforts. Areas particularly in need of research attention include investigation of the basic biology and optimal reproductive conditions of most freshwater snail species, assessment of genetic variation within snail populations, design of efficient equipment and techniques for captive propagation, and understanding of the nutritional needs of captive juvenile and adult snails, especially with regard to maximizing the growth rates of juveniles.

Efforts to conserve freshwater gastropods have lagged behind efforts to conserve freshwater mussels. However, this inequity is changing, and new initiatives are highlighting the need for gastropod conservation. We look forward with great optimism to a new national strategy for the conservation of all freshwater mollusk species. We also look with optimism to our conservation partners to establish and support active groups of interested publics working toward shared objectives. The challenges to conserving biodiversity are great, but we think that collective, coordinated efforts are no longer novel or incipient but are becoming mainstream with great successes on the horizon.

We are encouraged by the direction of molluscan research. We think that we can begin to prioritize freshwater snails in order of greatest conservation need so that we make the best use of limited resources once natural resource managers have reliable information on the species of mollusks present in their area of jurisdiction, the distribution and abundance of those species, and the persistence of those species in the face of environmental change. Natural resource managers and conservation organizations will continue to make decisions in the presence of significant uncertainty. The real challenge in conservation lies in the ability to develop a shared understanding among academics, natural resource managers, and the various publics we serve (Rogers 2006). We can increase our understanding and reduce uncertainty with regard to the conservation challenges we face if we follow a logical progression of information gathering, scientific understanding, and conservation advocacy.

\section{Acknowledgements}

The views expressed in our paper are those of the authors and not necessarily their supporting institutions. We thank the Freshwater Mollusk Conservation Society for the opportunity to present our work and for organizing this special issue. Brian Lang contributed information used in this manuscript. We express our gratitude to our supporting institutions for funding and material support, and we thank Caryn Vaughn, Pamela Silver, and 2 anonymous referees for constructive comments on previous drafts of this work.

\section{Literature Cited}

Armitage, P. D. 2006. Long-term faunal changes in a regulated and an unregulated stream-Cow Green thirty years on. River Research and Applications 22:947-966.

Brown, K. M. 2001. Mollusca: Gastropoda. Pages 297-329 in J. H. Thorp and A. P. Covich (editors). Ecology and classification of North American freshwater invertebrates. Academic Press, San Diego, California.

Brown, K. M., J. E. Alexander, and J. H. Thorp. 1998. Differences in the ecology and distribution of lotic pulmonate and prosobranch gastropods. American Malacological Bulletin 14:91-101.

Brown, K. M., AND P. D. JohnsOn. 2004. Comparative conservation ecology of pleurocerid and pulmonate gastropods of the United States. American Malacological Bulletin 19:57-62.

Brown, K. M., B. Lang, And K. E. Perez. 2008. The conservation ecology of North American pleurocerid and hydrobiid gastropods. Journal of the North American Benthological Society 27:484-495.

Burch, J. B. 1989. North American freshwater snails. Malacological Publications, Hamburg, Michigan.

Clark, G. M., R. R. Caldwell, T. R. Maret, C. L. Bowers, D. M. Dutton, And M. A. Beckwith. 2004. Water quality in the northern Rockies intermontane basins, Idaho, Montana, and Washington, 1999-2001. U.S. Geological Survey Circular 1235. US Geological Survey, Reston, Virginia.

Clark, G. M., and T. R. Maret. 1998. Organochlorine compounds and trace elements in fish tissue and bed sediments in the Lower Snake River Basin, Idaho and Oregon. U.S. Geological Survey Water Resources Investigations Report 98-4103. US Geological Survey, Reston, Virginia.

Dillon, R. T. 2000. The ecology of freshwater molluscs. Cambridge University Press, Cambridge, UK.

Dillon, R. T. 2007. Freshwater gastropods of North America project. (Available from: http://www.cofc.edu/ $\sim$ fwgna/fwgnahome.htm)

DunN, C. P. 2003. Keeping taxonomy based in morphology. Trends in Ecology and Evolution 18:270.

FisCHER, J., AND D. B. LiNDENMAYER. 2000. An assessment of the published results of animal relocations. Biological Conservation 96:1-11.

FREST, T. J., AND E. J. JoHANNES. 2000. An annotated checklist of Idaho land and freshwater mollusks. Journal of the Idaho Academy of Science 36:1-51.

Goldstein, P. Z., R. DeSalle, G. Amato, and A. P. Vogler. 2000. Conservation genetics at the species boundary. Conservation Biology 14:120-131.Graf, D. L. 2001. The 
cleansing of the Augean Stables, or a lexicon of the nominal species of the Pleuroceridae (Gastropoda: Prosobranchia) of recent North America, north of Mexico. Walkerana 12:1-124.

Griffith, B., J. M. Scott, J. W. Carpenter, And C. Reed. 1989. Translocation as a species conservation tool: status and strategy. Science 245:477-480.

Gurevich, J., AND D. K. Padilla. 2004. Are invasive species a major cause of extinctions? Trends in Ecology and Evolution 19:470-474.

Hall, R. O., M. C. Vanderloop, and M. F. Dybdahl. 2003. Exotic snails dominate nitrogen and carbon cycling in a highly productive stream. Frontiers in Ecology and the Environment 1:407-411.

Hershler, R. 1994. A review of the North American freshwater snail genus Pyrgulopsis (Hydrobiidae). Smithsonian Contributions to Zoology 554:1-115.

Hershler, R., H. Liu, T. J. Frest, and E. J. Johannes. 2007. Extensive diversification of pebblesnails (Lithoglyphidae: Fluminicola) in the upper Sacramento River basin, northwestern USA. Zoological Journal of the Linnean Society 149:371-422.

Hershler, R., ANd W. F. Ponder. 1998. A review of morphological characters of hydrobioid snails. Smithsonian Contributions to Zoology 600:1-55.

Hershler, R., AND D. W. SADA. 2002. Biogeography of Great Basin aquatic snails of the genus Pyrgulopsis. Smithsonian Contributions to the Earth Sciences 33:255-276.

Holznagel, W. E., AND C. LydeARD. 2000. A molecular phylogeny of North American Pleuroceridae (Gastropoda: Cerithioidea) based on mitochondrial $16 \mathrm{~S}$ rDNA sequences. Journal of Molluscan Studies 66:233-257.

Hutson, S. S., N. L. Barber, J. F. Kenny, K. S. Linsey, D. S. LuMIA, AND M. A. MAuPIN. 2005. Estimated use of water in the United States in 2000. U.S. Geological Survey Circular 1268. US Geological Survey, Denver, Colorado.

IUCN (INTERNATIONAL UNION FOR THE CONSERVATION OF NATURE and Natural Resources). 1998. Guidelines for re-introductions. Prepared by the IUCN/SSC Re-introduction Specialist Group. International Union for the Conservation of Nature and Natural Resources, Cambridge, UK. (Available from: http://www.iucn.org/)

JOHNSON, K. L., AND P. L. YounGER. 2006. The co-treatment of sewage and mine water in aerobic wetlands. Engineering Geology 85:53-61.

Kerans, B. L., M. F. Dybdahl, M. M. Gangloff, and J. E. JANNOT. 2005. Potamopyrgus antipodarum: distribution, density, and effects on native macroinvertebrate assemblages in the Greater Yellowstone Ecosystem. Journal of the North American Benthological Society 24:123-138.

Lipscomb, D., N. Platnick, AND Q. Wheeler. 2003. The intellectual content of taxonomy: a comment on DNA taxonomy. Trends in Ecology and Evolution 18:65-66.

Lydeard, C., R. H. Cowie, W. F. Ponder, A. E. Bogan, P. Bouchet, S. A. Clark, K. S. Cummins, T. J. Frest, O. Gargominy, D. G. Herbert, R. Hershler, K. E. Perez, B. Roth, M. Seddon, E. E. Strong, And F. G. Thompson. 2004. The global decline of nonmarine mollusks. BioScience 54: 321-330.
Lydeard, C., AND R. L. MAyden. 1995. A diverse and endangered aquatic ecosystem of the southeast United States. Conservation Biology 9:800-805.

Lyles, A. M., AND R. M. May. 1987. Problems in leaving the ark. Nature 326:245-246.

Lysne, S., AND P. KoEtsier. 2006. Experimental studies on habitat preference and tolerances of three species of snails from the Snake River of southern Idaho, U.S.A. American Malacological Bulletin 21:77-85.

Master, L. L., B. A. Stein, L. S. Kutner, And G. A. Hammerson. 2000. Vanishing assets: conservation status of U.S. species. Pages 93-115 in B. A. Stein, L. S. Kotner, and J. S. Adams (editors). Precious heritage, the status of biodiversity in the United States. Oxford University Press, New York.

McMahon, R. F., and A. E. Bogan. 2001. Mollusca: Bivalvia. Pages 331-429 in J. H. Thorp and A. P. Covich (editors). Ecology and classification of North American freshwater invertebrates. Academic Press, San Diego, California.

Miller, M. P., D. E. Weigel, AND K. E. Mock. 2006. Patterns of genetic structure in the endangered aquatic gastropod Valvata utahensis (Mollusca: Valvatidae) at small and large spatial scales. Freshwater Biology 51:2362-2375.

Myler, C. D., G. C. MladenKa, and G. W. Minshall. 2007. Trend analysis shows a decline for an endangered thermophilic springsnail (Pyrgulopsis bruneauensis) in southwest Idaho. Western North American Naturalist 67:199-205.

National Research Council. 2001. Compensating for wetland losses under the Clean Water Act. Committee on Mitigating Wetland Losses, Board on Environmental Studies and Toxicology, Water Science and Technology Board, National Research Council. National Academy Press, Washington, DC.

National Research Council. 2004. Valuing ecosystem services: toward better environmental decision-making. Committee on Assessing and Valuing the Services of Aquatic and Related Terrestrial Ecosystems, Water Science and Technology Board, National Research Council. National Academy Press, Washington, DC.

NAtURESERVE. 2007. NatureServe explorer: an online encyclopedia of life [web application]. Version 6.1. NatureServe, Arlington, Virginia. (Available from: http://www. natureserve.org/explorer)

Nebel, B. J., And R. T. Wright. 1996. Environmental science: the way the world works. Prentice Hall, Upper Saddle River, New Jersey.

Neves, R. J., A. E. Bogan, J. D. Williams, S. A. Ahlstedt, and P. W. HARTFIELD. 1997. Status of mollusks in the southeatern United States: a downward spiral of diversity. Pages 4385 in G. W. Benz and D. E. Collins (editors). Aquatic fauna in peril: the southeastern perspective. Special Publication 1. Southeast Aquatic Research Institute, Lenz Design and Communications, Decatur, Georgia.

Newbold, J. D., J. W. Elwood, R. V. O'Neill, and A. L. SHELDON. 1983. Phosphorous dynamics in a woodland stream ecosystem: a study of nutrient spiraling. Ecology 64:1249-1265.

NNMCC (National Native Mussel Conservation Committee). 
1998. National strategy for the conservation of native freshwater mussels. Journal of Shellfish Research 17: 1419-1428.

NOAA (National Oceanic and Atmospheric Administration). 2007. Salmon recovery planning strategy. Northwest Regional Office, National Marine Fisheries Service, National Oceanic and Atmospheric Administration, Seattle, Washington. (Available from: http://www.nwr.noaa. gov/Salmon-Recovery-Planning/Recovery-Strategy.cfm)

Perez, K. E., And R. L. Minton. 2008. Practical applications for systematics and taxonomy in North American freshwater gastropod conservation. Journal of the North American Benthological Society 27:471-483.

Poff, N. L., J. D. Allan, M. B. Bain, J. R. Karr, K. L. Prestegandd, B. D. Richter, R. E. Sparks, and J. C. STROMBERG. 1997. The natural flow regime a paradigm for river conservation and restoration. BioScience 47:769782.

Postel, S. L. 2000. Entering an era of water scarcity: the challenges ahead. Ecological Applications 10:941-948.

Prato, T., AND D. Hey. 2006. Economic analysis of wetland restoration along the Illinois River. Journal of the American Water Resources Association 42:125-131.

Rattray, G. W., A. J. WehnKe, L. F. Hall, and L. C. Campbell. 2005. Radiochemical and chemical constituents in water from selected wells and springs from the southern boundary of Idaho National Laboratory to the Hagerman Area, Idaho, 2003. U.S. Geological Survey Open File Report 2005-1125. Version 2.1. US Geological Survey, Reston, Virginia.

Richards, D. C. 2004. Competition between the threatened Bliss Rapids snail, Taylorconcha serpenticola (Hershler et al.) and the invasive, aquatic snail Potamopyrgus antipodarum (Gray). PhD Dissertation, Montana State University, Bozeman, Montana.

Richards, D. C., AND D. CAZIER-Shinn. 2004. Intraspecific competition and development of size structure in the invasive snail Potamopyrgus antipodarum (Gray, 1853). American Malacological Bulletin 19:33-37.

Richardson, T. D., J. F. Schiering, AND K. M. Brown. 1988. Secondary production of two lotic snails (Pleuroceridae:Elimia). Journal of the North American Benthological Society 7:234-245.

Rogers, K. H. 2006. The real river management challenge: integrating scientists, stakeholders and service agencies. River Research and Applications 22:269-280.

SADA, D. W., AND G. L. VinYARD. 2002. Anthropogenic changes in biogeography of Great Basin aquatic biota. Smithsonian Contributions to the Earth Sciences 33:277-293.

SARRAZIN, F., AND R. BARBAult. 1996. Reintroductions: challenges and lessons for basic ecology. Trends in Ecology and Evolution 11:474-478.

SeberG, O., C. J. Humphries, S. Knape, D. W. Stevenson, G. Petersen, N. Scharff, And N. M. Andersen. 2003. Shortcuts in systematics? A commentary on DNA-based taxonomy. Trends in Ecology and Evolution 18:63-65.

Seddon, P. J., D. P. Armstrong, and R. F. Maloney. 2007. Developing the science of reintroduction biology. Conservation Biology 21:303-312.
Seddon, P. J., P. S. Soorae, and F. Launay. 2005. Taxonomic bias in reintroduction projects. Animal Conservation 8: 51-58.

SimberLOFF, D. 2003. Confronting introduced species: a form of xenophobia? Biological Invasions 5:179-192.

Sites, J. W., AND J. C. Marshall. 2004. Empirical criteria for delimiting species. Annual Review of Ecology and Systematics 35:199-229.

SNYDER, N. F. R., S. R. DerRickson, S. R. Beissinger, J. W. WiLey, T. B. Smith, W. D. ToOne, AND B. Miller. 1996. Limitations of captive breeding in endangered species recovery. Conservation Biology 10:338-348.

STEWART, T. W. 2006. The freshwater gastropods of Iowa (1821-1998): species composition, geographic distributions, and conservation concerns. American Malacological Bulletin 21:59-76.

Stewart, T. W., AND R. T. Dillon. 2004. Species composition and geographic distribution of Virginia's freshwater gastropod fauna: a review using historical records. American Malacological Bulletin 19:79-92.

TAYLOR, D. W. 2003. Introduction to Physidae (Gastropoda: Hygrophila); biogeography, classification, morphology. Revista de Biología Tropical 51:1-287.

TE, G. A. 1978. A systematic study of the family Physidae. PhD Dissertation, University of Michigan, Ann Arbor, Michigan.

TRYON, G. W. 1873. Land and fresh-water shells of North America. Part IV. Strepomatidae. Smithsonian Miscellaneous Collections 16:1-435.

Turgeon, D. D., J. F. Quinn, A. E. Bogan, E. V. Coan, F. G. Hochberg, W. G. Lyons, P. M. Mikkelsen, R. J. Neves, C. F. E. Roper, G. Rosenberg, B. Roth, A. Scheltema, F. G. Thompson, M. Vecchione, And J. D. Williams. 1998. Common and scientific names of aquatic invertebrates from the United States and Canada: mollusks. Special Publication 26. American Fisheries Society, Bethesda, Maryland.

USFWS (US Fish And Wildlife Service). 2000. Policy regarding controlled propagation of species listed under the Endangered Species Act. Federal Register 65:5691656922.

USFWS (US Fish AND Wildlife SERVICE). 2006. Draft national bald eagle management guidelines. US Fish and Wildlife Service, Washington, DC. (Available from: http://www. fws.gov/migratorybirds / issues / BaldEagle/Mgmt. Guidelines.2006.pdf)

Wilson, E. O. 2005. Systematics and the future of biology. Proceedings of the National Academy of Sciences of the United States of America 102:6520-6521.

Wong, C. S., P. D. Capel, AND L. H. Nowell. 2000. Organochlorine pesticides and PCBs in stream sediment and aquatic biota-initial results from the National Water Quality Assessment Program, 1992-1995. U.S. Geological Survey Water-Resources Investigations Report 00-4053. US Geological Survey, Sacramento, California.

Received: 21 June 2007 Accepted: 12 February 2008 